\title{
The Native Plant Enthusiasm: Ecological Panacea or Xenophobia?
}

\author{
Gert Gröning and Joachim Wolschke-Bulmahn
}

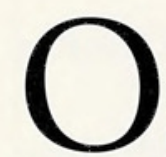

ver the last two decades, landscape designers have tended to avoid the use of plants that are labeled exotic, or nonnative. Many professionals and laypeople who are interested in nature, landscape, and gardens assume that what they believe are indigenous, or native, plants are unquestionably better than those that are not.

A number of years ago (1986) Reinhard Witt, a German biologist and advocate of "nature gardens," published an article entitled "Tear the rhododendrons out!" Witt demanded the liberation of gardens in Germany from foreign trees and shrubs, especially rhododendrons. Similarly, Leslie Sauer, an American landscape architect, wrote that only the North Woods area of New York's Central Park was "healthy" since it was free of exotic plants; she rated other parts of Central Park as "degraded areas." This hostility toward foreign plants appears to be a phenomenon in many countries around the world.

The distinction between native and nonnative plants has a long history; it may be as old as concepts of nations and of native and foreign people. For example, in 1629 the Englishman John Parkinson published his book Paradisi in sole paradisus terrestris. Parkinson presented plants "that are called usually English flowers" and "outlandish flowers" in a remarkably unbiased way. He knew already that

those flowers that have been usually planted in former times in Gardens of this Kingdom ... have by time and custome attained the name of English flowers, although the most of them were never naturall of this our Land, but brought in from other countries at one time or other, by those that tooke pleasure in them where they first saw them.

Although there are a few studies along similar lines published in the late twentieth century, this historical knowledge of how foreign plants became native seems to have faded. Not long ago the late Stephen Jay Gould offered a fascinating discussion of the concept of native plants: "this notion encompasses a remarkable mixture of sound biology, invalid ideas, false extensions, ethical implications, and political usages both intended and unanticipated." Natives, according to Gould,

are only those organisms that first happened to gain and keep a footing ... In this context, the only conceivable rationale for the moral or practical superiority of "natives" (read first-comers) must lie in a romanticized notion that old inhabitants learn to live in ecological harmony with surroundings, while later interlopers tend to be exploiters. But this notion, however popular among "new agers," must be dismissed as romantic drivel. ${ }^{1}$

Those who doctrinarily plead for native plants often also condemn foreign or exotic plants as aggressive intruders, thus suggesting that native plants are peaceful and noninvasive. Numerous publications give evidence of this biased viewpoint. In an article "Wildflowers: the case for native plants," for example, it is stated that some nonnative, naturalized wildflower species in the United States exhibit "aggressive, weedy behavior." Characterizations such as "invasive exotic weeds," "non-indigenous invasive weeds," "exotic species invasions," and "foreign invaders" are common.

Advocates of native-plant use tend to ascribe high moral qualities to themselves and to their followers. An essential part of this realm of moral qualities is the idea of the nation. This idea developed in the Western world in the course of the nineteenth and twentieth centuries at the same time as disciplines such as plant geography, plant ecology, and plant sociology were being established. At the beginning, scholars in these disciplines were internationally 


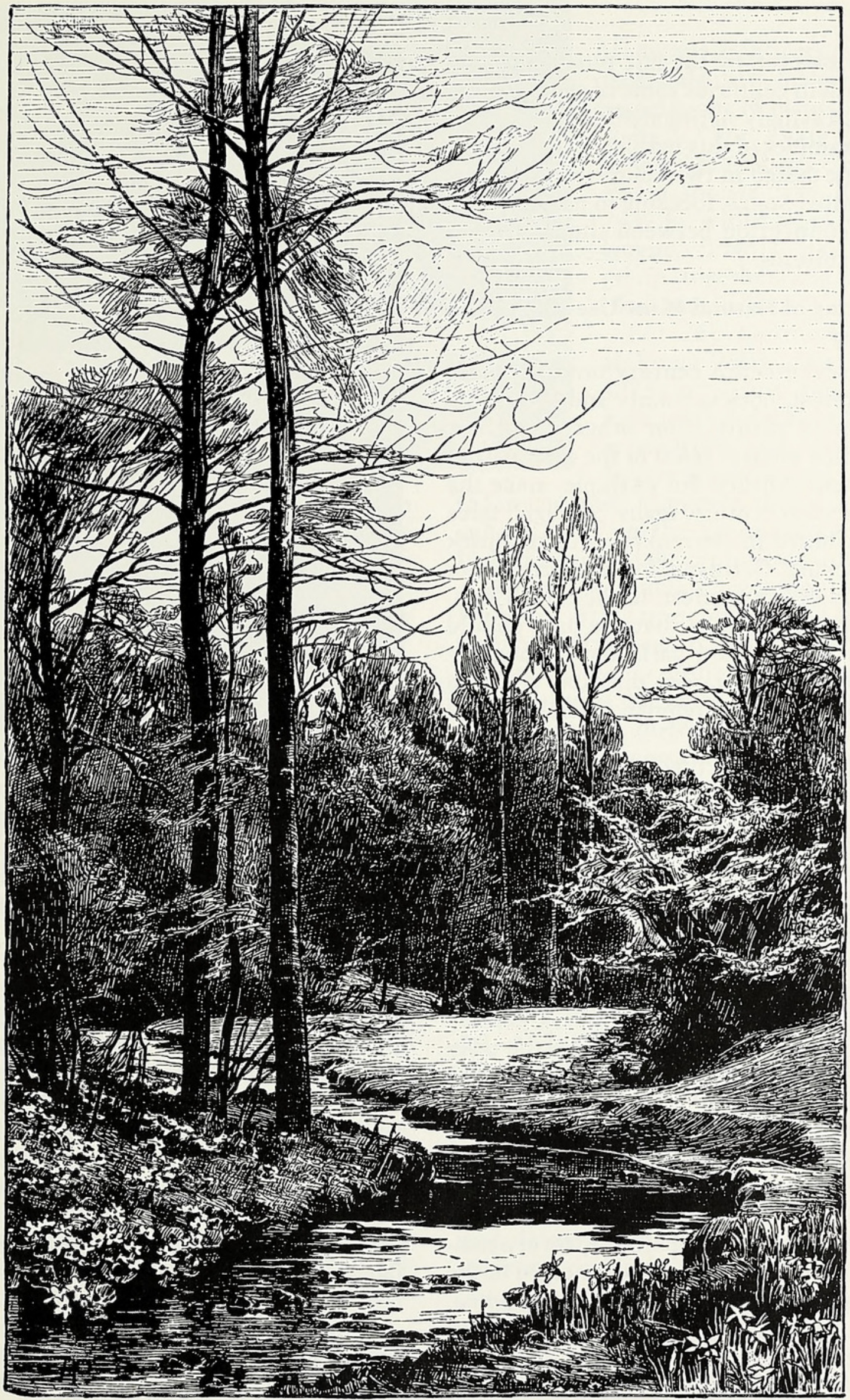

"Valley in Somersetshire, with Narcissi, Marsh Marigolds, and Primroses" from William Robinson's The Wild Garden, 1883. 
oriented. However, by the late nineteenth and early twentieth centuries some of their writing turned increasingly nationalistic. This article explores examples of this nationalistic ideology in landscape design in two countries, Germany and the United States, focusing in particular on points of connection between their national landscape cultures.

\section{The Doctrine of Natural Plant Use in Germany}

From the seventeenth century onward, there was an interest, both scholarly and lay, in the cultivation of plants from other countries. However, this interest faded in the early part of the twentieth century. For example, since the early nineteenth century, many "foreign" trees had been planted in Herrenkrugwiesen, a park near Magdeburg, Germany, for scholarly rather than merely design interest. In the early 1900s, however, it was decided that the park should be changed to a meadow-park, and public pressure forced the then garden director, Wilhelm Lincke (1866-1912), to remove already-planted "foreigners."

With regard to the actual design of parks and gardens in Germany, such public pressure was not predominant, but it can be seen as an aspect of a reactionary national ideology that would soon dominate German society. Similar trends might be seen in other industrial countries in the late nineteenth and early twentieth centuries, at the high point of imperialism. In England, for instance, William Robinson and others searched for the truly English garden. In France, André Vera was looking for the truly French garden. In the United States, as we will see later, Jens Jensen, Wilhelm Miller, and Frank A. Waugh tried to pull away from the garden design of the Old World in order to establish a genuinely American garden style clearly distinguished from the European. Only in Germany, however, did this interest become part of a radical nationalistic movement that emerged in the early twentieth century. It was enforced when, in January 1933, the National Socialist German Workers' Party came to power. Then, a nationalistic antagonism toward anything foreign and nonGerman, which had been common in factions of German society, turned into a powerful public movement.
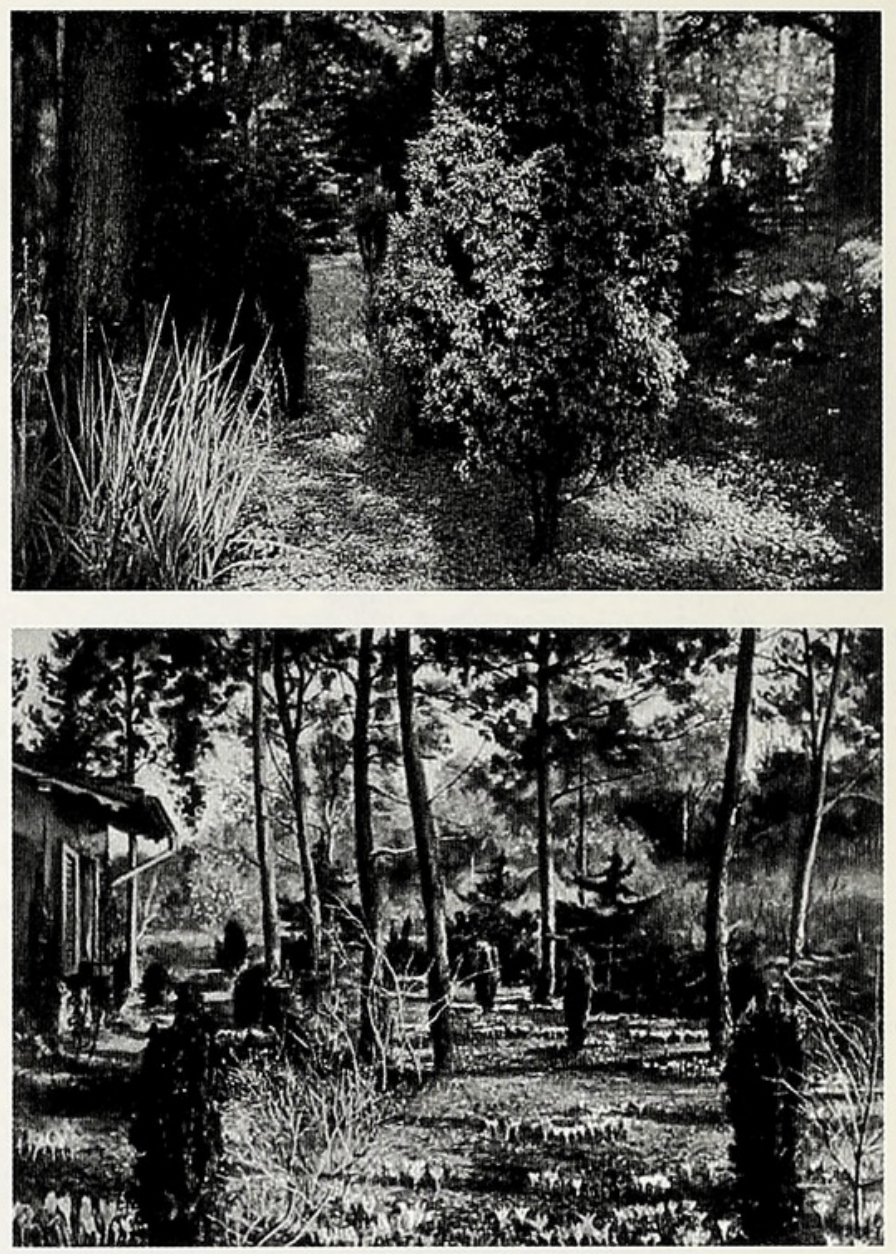

Nature garden motifs by Willy Lange. Above, from Lange's Gartengestaltung der Neuzeit, 1907 and 1928, and on the facing page, from his Der Garten und seine Bepflanzung, Das Leben der Pflanze, 1913.

In the early twentieth century, modern German garden design followed trends in architecture and the arts. New ways of aesthetic expression as well as new forms of social life were being explored. Many people attempted to escape what were perceived as outdated, latenineteenth-century customs. The new approach was associated with, for instance, Cubism, Expressionism, and Functionalism, which to some extent found their way into garden design. In reaction to that modern aesthetic, others advocated the modern concepts of "natural" garden design and claimed to apply the most recent scientific findings of ecology and plant sociology. In 1913 Willy Lange (1864-1941) presented such an approach in landscape architecture. ${ }^{2}$

Lange's "biological aesthetic" was modern in the sense that it applied science to design. But from a social perspective it was reactionary, promoting dubious ideas about the assumed relationship between the German people and nature and provoking within particular groups hostility 


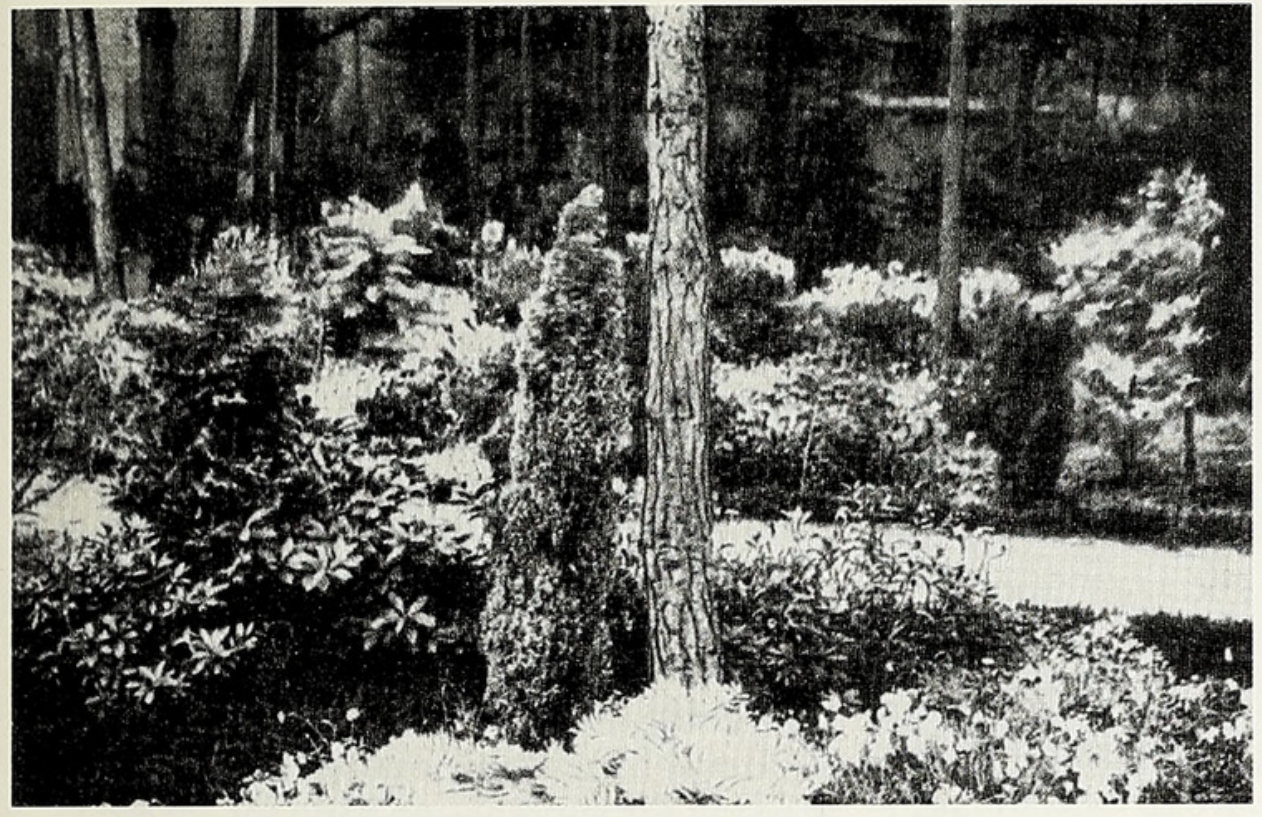

toward the "international" by excluding foreign plants. The emerging science of ecology was the instrument for this naturalistic trend in garden design, which depended on the notion of natural associations of plants. The starting point for ecology as "a definite science" was the publication in 1895 of Ecology of Plants: an introduction to the study of plant communities by the Danish scientist Eugen Warming (18411924), subsequently translated into German and English.

Around 1900 the term plant sociology was coined and was most influentially developed by Josias Braun-Blanquet, who published his book Plant Sociology: the study of plant communities in 1928. In this book he popularized the doctrine of plant sociology and defined its subject as follows: "Every natural aggregation of plants is the product of definite conditions, present and past, and can exist only when these conditions are given. The whole structure of plant sociology rests upon this idea of sociological determination." Braun-Blanquet maintained that sociology and plant sociology "have one important point of contact: they are concerned not with the expression of life of the individual organism as such but with groups or communities of organisms having more or less equivalent reactions, bound together in mutual dependence."

The ideology of "blood and soil" was taking hold in Germany in a context of increasing racism and nationalism in Europe, and the doctrine of plant sociology fascinated many a landscape architect. As we shall see later, American landscape architects such as Jens Jensen also saw analogies between associations of plants and human society. For example, Jensen believed that plants communicate and associate like humans. In 1939 he wrote to a German colleague, "Plants, like ourselves, group together and have their likes and dislikes." ${ }^{\prime 3}$

For the German landscape architect Willy Lange, writing in 1928, a "nature garden" would have an informal rather than a geometric or architectural design. Native plants would be preferred to foreign ones. ${ }^{4}$ Moreover, the garden had to be subordinated to the surrounding landscape. Lange considered the centuries-old art of topiary as evidence of human hegemony over nature. For him, cutting trees, shrubs, and hedges was a form of anthropocentric dominance over nature and an expression of the unnatural attitudes of other cultures that were at lower stages of cultural evolution. Instead, humans should follow and augment the so-called laws of nature spiritually, arranging nature artistically in the form of the nature garden.

For a "true" German in those days, culture could only be national culture. ${ }^{5}$ Consequently Lange saw garden art as a constituent of national culture. He strongly rejected the idea that "art could be international" and proclaimed: "Let us find the national style for our gardens, then we will have art, German garden art. As long as different nations exist, there must exist different national styles." Lange's idea of nationality assumed that there was a ranking of cultures: for him the superiority of the German people was part of their national identity. For Lange, the German people were rooted in the soil, and every German required and deserved an appropriate natural-spatial environment. In 1907 he wrote:

Our feelings for our homeland should be rooted in the character of domestic landscapes; therefore it is German nature that must provide all ideas for the design of gardens. They can be heightened by artistic means, but we must not give up the German physiognomy. Thus, our gardens become German if the ideas for the 


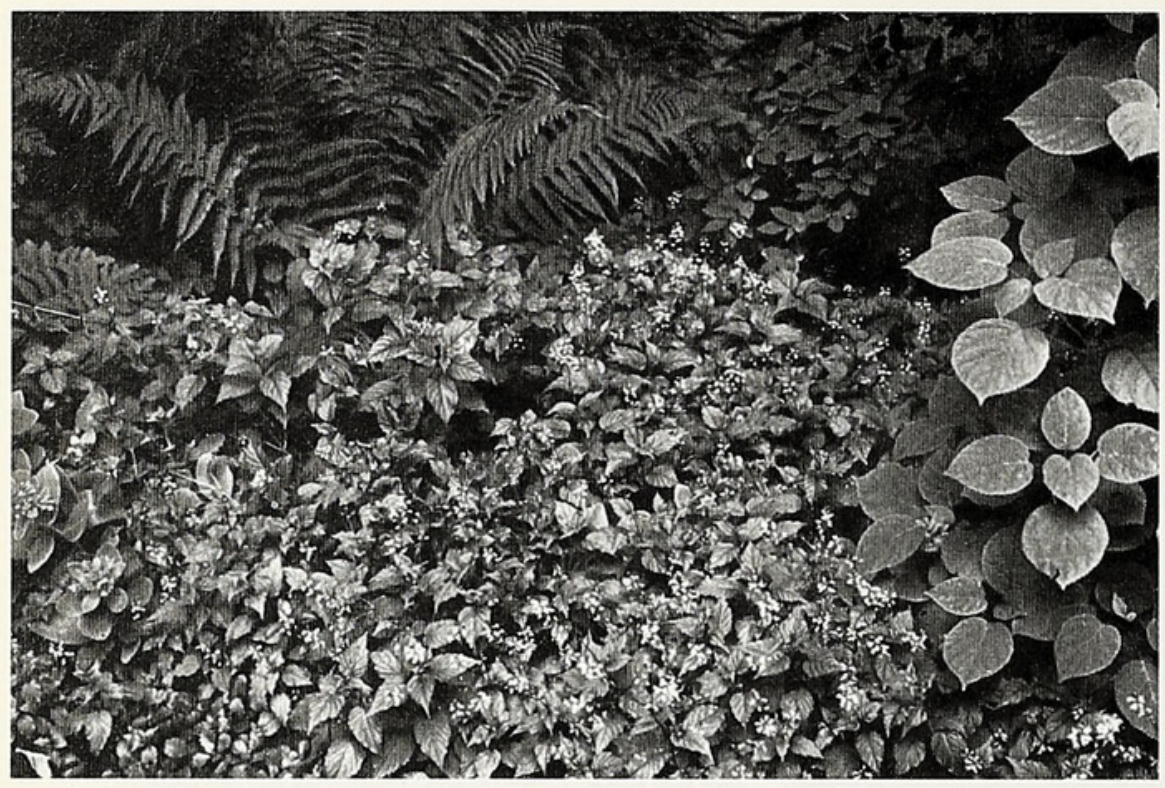

In July 1932 Seifert recommended these natives of Germany's mountain forests to the readers of Gartenschönheit, writing, "We have no overabundance of summer-blooming perennials for the rock garden. It is amazing that such an attractive and easy-to-care-for little herb like Circaea [enchanter's nightshade] is so little known." intended to strengthen a nationally oriented culture against modern and international tendencies in the arts. Seifert deliberately introduced the "rootedness" category into the art of gardening because he "wanted to bring garden art into the struggle in all living spaces which has broken out in our days between 'rootedness in the soil' and 'supranationality.'" Later, when Seifert became one of the leading landscape architects of National Socialism, he elaborated on this struggle as "a fight between two opposing Weltanschauungen: on one side the striving for supranationality, for leveling down of huge areas, and on the other the elaboration of the peculiarities of small living spaces, emphasizing that which is rooted in the soil." Seifert design are German, especially if they are borrowed from the landscape in which the garden is located.

Such a view was popular not only during the Imperial Reich in Germany, but continued through the Weimar Republic and became part of the state doctrine during National Socialism.

Given the variety of what could have been regarded as landscape in Germany, we might expect Lange to have suggested a matching number of natural garden designs. However, he believed three types to be sufficient for all German natural garden design: a "mountain," a "middle," and a "plains" landscape. The American landscape architect Frank A. Waugh (18691943), who had studied garden design with Lange in 1910 at the institution for teaching and research in horticulture (Gärtnerlehranstalt) in Berlin-Dahlem, similarly distinguished for the United States just four "principal types of native landscapes: the sea landscape, the mountains, the plains, and the forests." As a result of this narrow range of recognized landscapes, nature garden advocates such as the German Alwin Seifert (1892-1972) felt they had to work with a "fate-determined poverty of plants" in a "nature garden."

In 1929 Seifert used the term "rootedness in the soil" for his concept of a natural garden design in two articles published in Die Gartenkunst (Garden Art). Such a garden was echoed Lange, who in 1907 had praised the "rediscovery of so-called folk art; the stressing of one's own folk character-in opposition to the glorification of the international, in reality non-national."

During National Socialism, the subordination of the design to the dictates of what were then considered national landscapes and native plants turned into a doctrine. Racist, nationalistic, and so-called ecological vocabulary served landscape architects in their attempts to eliminate foreign plants from German soil. For example, in 1936 the German landscape architect Albert Krämer argued that the Germans

still lack gardens that are race-specific, that have their origins in nationality and landscape, in blood and soil. Only our knowledge of the laws of the blood, and the spiritually inherited property and our knowledge of the conditions of the home soil and its plant world (plant sociology) enable and oblige us to design blood-and-soilrooted gardens.

Similarly, a team of Saxon botanists militantly equated their fight against foreign plants with the fight of Nazi Germany against other nations, especially "against the plague of Bolshevism." The team demanded "a war of extermination" against Impatiens parviflora, a little herb that grows in lightly shaded areas in forests. These professionals regarded I. parviflora as a stranger that dared to spread and even 
compete with $I$. noli tangere, a similar but larger species that was considered native. Presumably, the stranger endangered the purity of the German landscape, and in their final sentence the botanists extended their claim dramatically: "As with the fight against Bolshevism, our entire occidental culture is at stake, so with the fight against this Mongolian invader, an essential element of this culture, namely, the beauty of our home forest" is at stake.

\section{Concepts of Natural Garden Design in the United States}

The concern that emerged in Germany for a national style of garden was also evident among some U.S. landscape architects. They preferred native plants in their early twentieth-century American garden and landscape designs. Some even believed in the exclusive use of native plants. Such claims in the United States were made most emphatically by Jens Jensen (1860-1951), Wilhelm Miller (1369-1938), and Frank A. Waugh (1869-1943). Here we will discuss Miller's and Jensen's ideas.

In 1915 Wilhelm Miller published a booklet, The Prairie Spirit in Landscape Gardening, in which he outlined his idea of a regional garden style that he felt was representative of midwestern landscapes. For him, "the prairie style of landscape gardening is an American mode of design based upon the practical needs of the middle-western people and characterized by preservation of typical western scenery, by restoration of local color, and by repetition of the horizontal line of land or sky which is the strongest feature of prairie scenery." The disciplines that should assist the design of this garden style were systematic botany, state and local history, and ecology. For Miller, ecology was "a new and fascinating branch of botany that deals with plant societies."

Thus not only science and history were incorporated into garden design, but also the sense of a region-the Midwest, not in fact a particularly

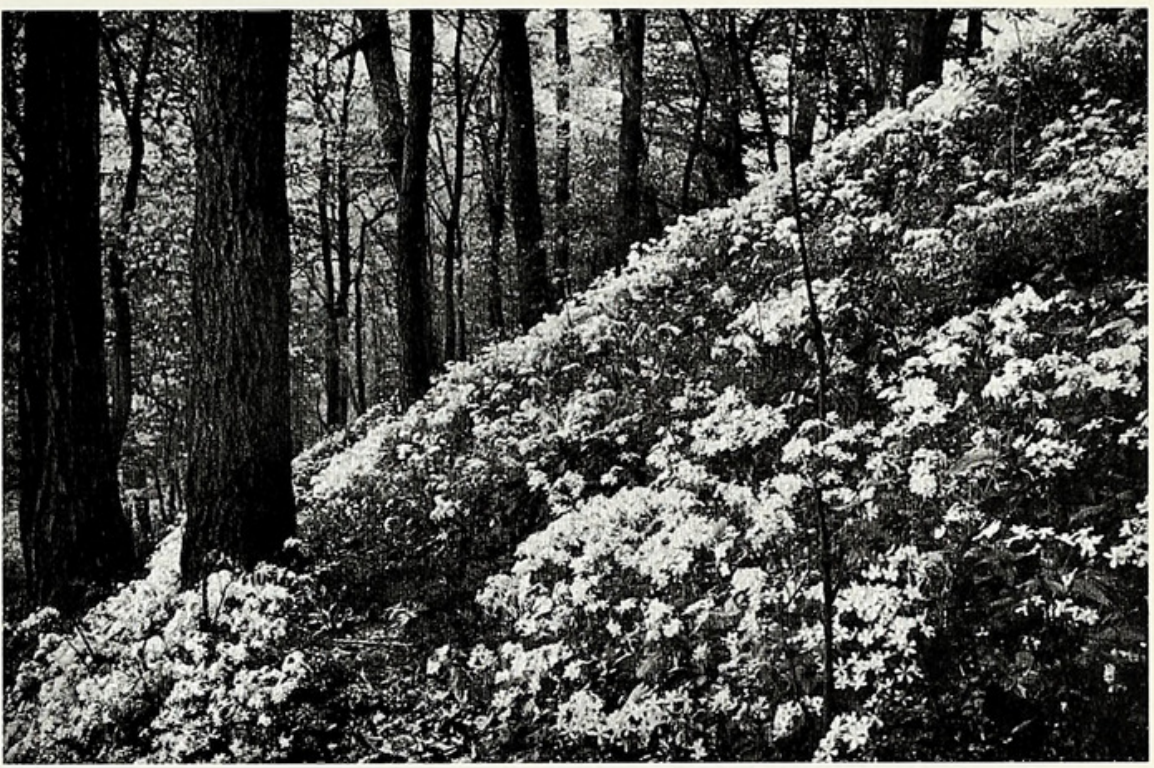

In his 'Illinois' Way of Beautifying the Farm, 1914, Miller captioned this photo, "A Woodlot Full of Wild Flowers-No Cows," noting that

"The wild blue phlox (Phlox divaricata) once carpeted the woodlands of Illinois and tens of thousands of their thrilling blue flowers could be seen in May. They will come back and stay, if you will spend \$2 for enough three-strand wire to inclose an acre."

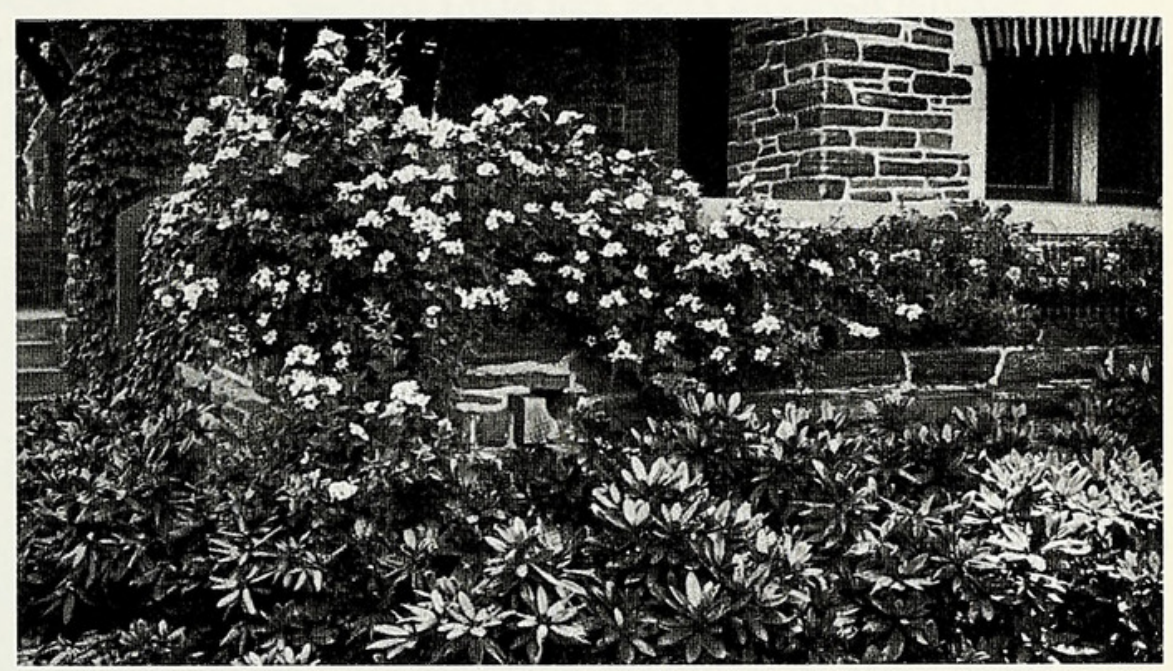

For porch decoration Miller also recommended another prairie native: "This country home has privacy enough without training the roses up to hide the porch. The object here is to decorate the porch, and this shows what kind of garland you can make with the Illinois or prairie rose (Rosa setigera). The bushes in the foreground are rhododendrons, which are impractical for Illinois, but we can get a unique effect by replacing them with Illinois roses. Let most of them make compact bushes to hide the foundation, and train a few to make garlands. Why not a whole porch, now and then, planted exclusively or chiefly with Illinois roses?"

well-defined geographical area, but certainly a large region relative to the size of some European states. With his proposal for a regional garden style for the Midwest, Miller reacted against the garden design that had become popular among wealthy garden owners in the Northeast and that he feared would become the prevailing 
style. He complained, for instance, about "great excesses of artificiality, especially in the East, where rich men's gardens are often loaded with globes, cones, pyramids, cubes, and columns of evergreen foliage." Miller wanted the design of gardens to correspond to what he believed were the more modest means of the Midwest.

Like Miller, the American landscape architect Jens Jensen opposed the use of nonnative plants in American parks and gardens and promoted the regional prairie style. To understand Jensen's work, his plea for the use of native plants, and his concept of garden design, we need to consider his ideas about the relationships among people, races, and nature. Jensen believed that ideas about nation, race, and the natural environment are closely interwoven. In an article on the art of landscaping published in 1923 in the German journal Die Gartenschönheit (Garden Beauty), Jensen drew a parallel between races and plant species:

Perhaps it may be too restricted to design a landscape picture only by the means of simple indigenous plants. But please consider that it was them amongst whom we grew up, that they taught us a particular language without interruption since the earliest days of our tribe, that they are interwoven with the soul of our race and, indeed, no art of landscape gardening will be called true art and will be able to reflect the soul of a tribal people, if it does not take its means of expression from the environment of these people.

These ideas were further developed in his 1939 book Siftings. In drawing a connection between race and landscape, Jensen wrote of "the soul of our native landscape. Nothing can take its place. It is given to us when we are born, and with it we live." With respect to the art of garden design he ruled, "art must come from within and the only source from which the art of landscaping can come is our native landscape. It cannot be imported from foreign shores and be our own." For Jensen, "no plant is more refined than that which belongs. There is no comparison between native plants and those imported from foreign shores which are, and shall always remain so, novelties." The fact that Jensen himself was born in Denmark and had lived there for more than twenty years, yet could presume to develop the American "Prairie Style," might cast some doubt on the idea of any congenital relationship of humans to particular landscapes.

In 1939, at the high point of National Socialist power in Germany, Jensen wrote a letter to his German colleague Camillo Schneider in Berlin. His letter discussed Alwin Seifert, who as noted above, fully supported National Socialism and was arguing that landscape design in Nazi Germany must stand by the "fatedetermined poverty of plants." But where Seifert allowed slightly fewer native plants in a garden, Jensen took a more uncompromising position:

Seifert seems to distinguish between the garden inside an enclosure and the landscape-here he submits to compromise... I cannot see how you can compromise on a difference between the garden and its surroundings, then the garden remains a stranger in its own land. To be true to yourself, I mean true to your native landscape is

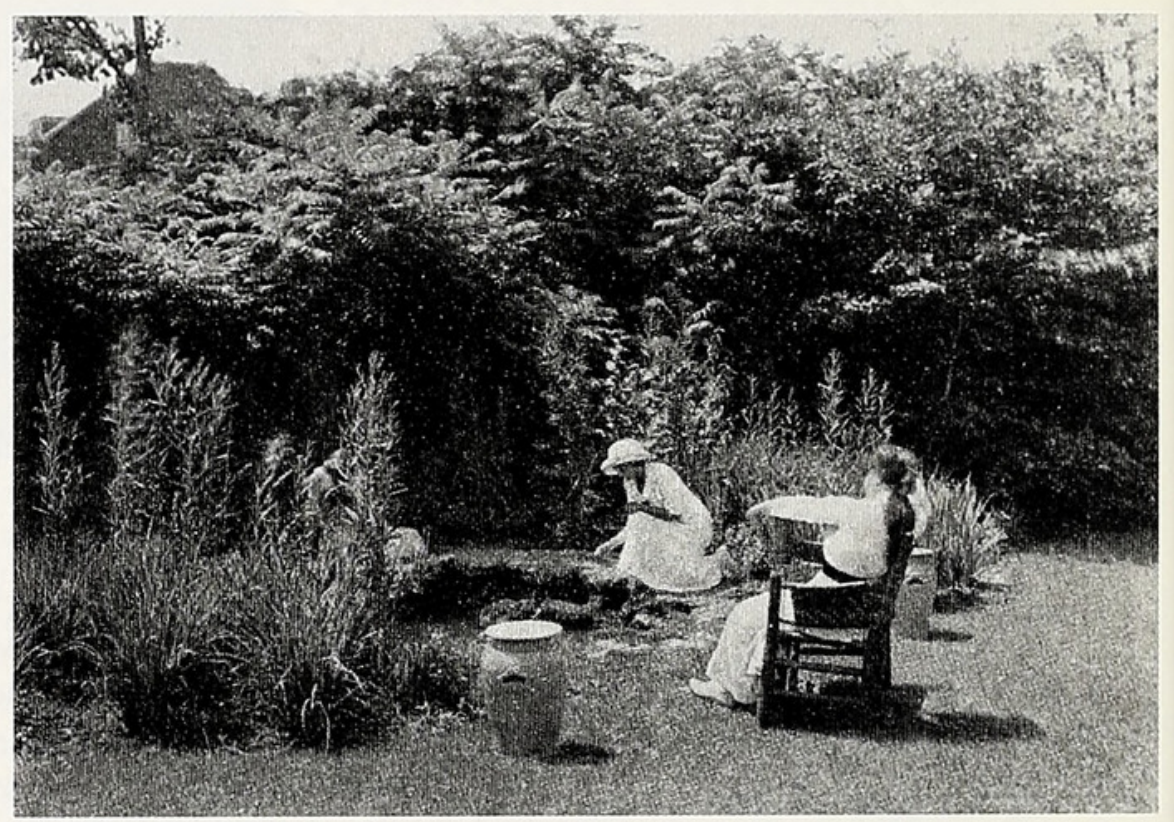

Both Waugh and Miller used illustrations of Jensen's designs in their books. This is from Waugh's 1917 The Natural Style in Landscape Gardening, where he captioned it, "Naturalistic Composition. Back Yard Garden." Elsewhere in his text he wrote, "Certainly he would be a hard theorist and an intolerable puritan who would exclude the common lilac and the homely apple tree from his grounds simply because they are not native to America. It wouldn't be good democratic Americanism, either, for the great bulk of our citizens are derived from foreign stocks." 


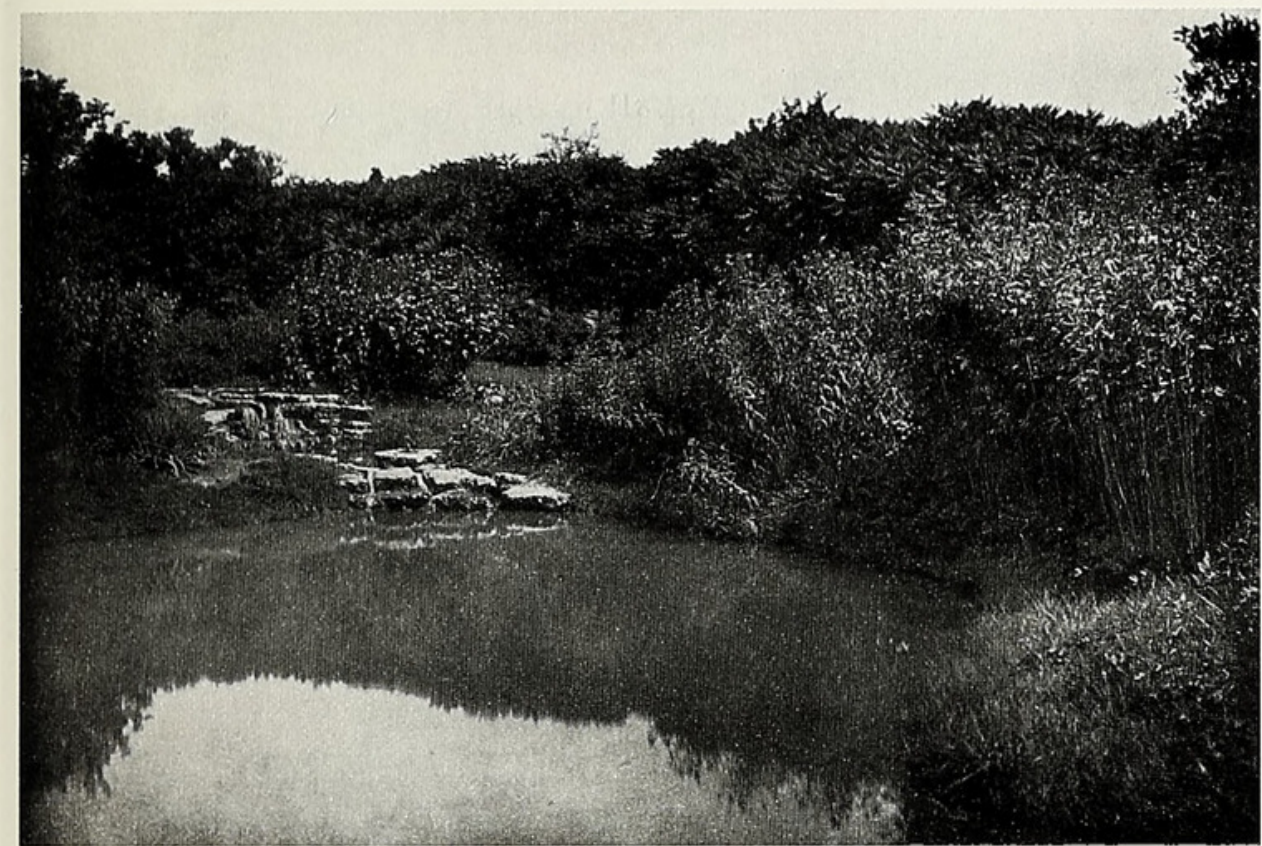

Miller, again in 1914, presented a photograph of Jensen's Humboldt Park in Chicago, writing: "The people of Chicago have created at great expense the sort of thing every farmer can enjoy for nothing. This prairie river landscape was designed by Jensen, and planted with common Illinois flowers, e.g., swamp rose mallow, blue flag, water-lily, calamus, phlox, etc."

a very fundamental issue-it is to be, or not to be. In the garden you give assent to one idea and outside its boundary to another. Strange things, grotesque things, usually attractive to the novice will creep in and the purity of thoughts in garden making suffers. Freaks are freaks and often bastards-who wants a bastard in the garden, the out of door shrine of your home?

In his return letter, Schneider rejected Jensen's view of the "native landscape" and wrote that, if one agreed with Jensen's point of view, one would have to get rid of all English gardens and would have to switch off all joy in the "foreign'" which "would mean a severe impoverishment." Schneider also believed it necessary

to clearly separate the notions of "landscape" and "garden" ... In a garden one consciously wants to create something completely different from what nature at home can offer which one can enjoy during car rides and hiking tours. Where else would one enjoy what beautiful things we happen to have received from foreign countries?

But Jensen saw this as a failure of intellect.

The garden is a fine barometer by which to judge the intellect of a people. If the garden which is a true expression of the life of a people will not consist of horticultural specimens, rather of a simple arrangement of plants in a harmonious whole-that is art. The other is science or decoration. It takes a higher intellect to create a garden out of a few plants than of many.

Jensen had clearly indicated how racism was an important motif in his plea for native plants in his 1937 article "Die 'Lichtung'" [The Clearing], published in Die Gartenkunst:

The gardens that I created myself shall . . . be in harmony with their landscape environment and the racial characteristics of its inhabitants. They shall express the spirit of America and therefore shall be free of foreign character as far as possible... The Latin and the Oriental crept and creeps more and more over our land, coming from the South, which is settled by Latin people, and also from other centers of mixed masses of immigrants. The Germanic character of our race, of our cities and settlements was overgrown by foreign character. Latin spirit has spoiled a lot and still spoils things every day.

Such ideas about the alleged negative influence of so-called Latin people were clearly in line with the National Socialist agenda. But Jensen was forced to step back from further expression of his racist ideas by correspondence from Harold LeClaire Ickes (1874-1952), the U.S. Secretary of the Interior from 1933 until 1946, who had learned about Jensen's leanings toward anti-Semitism.

In Germany as well as in the United States, a critical discussion of the enthusiasm for native plants often provokes emotionally loaded responses. Two examples might illustrate this. The first one is a series of papers and letters published in the Landscape Journal that began in 1992 with our article "Some notes on the mania for native plants in Germany." This article was the starting point for a heated debate in the journal that lasted for several years. The title of one of the responses may indicate the trend, "Natives and Nazis: an imaginary conspiracy in ecological design." The author, professor of 
natural systems in the School of Architecture and Planning at the University of New Mexico, began with "Rhododendrons in the gas chambers! Kristallnacht against Kudzu! Gert Gröning and Joachim Wolschke-Bulmahn attempt to link native-plant advocates with Nazism."

The second example is a response to Michael Pollan's article "Against Nativism," published in 1994 by the New York Times Magazine, which became the target of highly emotional attacks. William K. Jordan III, for instance, opened his "The Nazi Connection" with this complaint:

Several times in the past few years I have been brought up short by the suggestion that ecological restoration is a form of nativism-the ecological version of the sort of racist policies espoused by the Nazis or the Ku Klux Klan. Like the Nazis and the Klan, restorationists espouse the exclusion and removal of immigrants, and even a program to ensure genetic purity of stock in order to protect the integrity of the native, the true-born, the Blut und Boden. Hence restoration offers a disturbing resemblance in the ecological sphere to policies of nativism, racism, and sexism in the social sphere-so the argument goes.

If there is a future to garden culture and garden design, then new ideas, new concepts for gardens, new plants, and new materials are essential. The history of garden culture provides ample evidence for the multitude of connections among people, politics, design, and plants. Militant calls such as "foreigners out" or, more specifically, "Tear the rhododendrons out" seem not particularly well-considered solutions to what are called ecological problems. Such calls transmit reactionary ideas about society as well as nature, the design of gardens, parks, and other open spaces. Rather, a temperate and informed discussion about plants, trees, shrubs, their value, and their significance for design should develop, and for that a look into history may be helpful. There is no need to glorify historical events. Professional development could profit from critical analyses of the work and ideas of predecessors in biology, botany, garden and landscape design.

The Jewish writer Rudolf Borchardt, who was persecuted by the National Socialists, offered an important criticism of doctrinaire advocates of native-plant use that is still relevant today. $\mathrm{He}$ wrote in 1938:

If this kind of garden-owning barbarian became the rule, then neither a gillyflower nor a rosemary, neither a peach tree nor a myrtle sampling nor a tea rose would ever have crossed the Alps. Gardens connect people, time, and latitudes. If these barbarians ruled, the great historic process of acclimatization would never have begun and today we would horticulturally still subsist on acorns ... The garden of humanity is a huge democracy. It is not the only democracy that such clumsy advocates threaten to dehumanize.

\section{Notes}

${ }^{1}$ Stephen Jay Gould's "An Evolutionary Perspective on Strengths, Fallacies, and Confusions in the Concept of Native Plants" was reprinted in Arnoldia (1998) $58(1)$.

${ }^{2}$ In a statement shortly before the First World War, Lange claimed that scientific progress would influence garden design: "Today we have a natural science that is based on the history of development. It teaches us, as far as the interrelations between creatures with their homeland and their fellow creatures are concerned, to understand the laws of life. Biology penetrates all previous knowledge, which was only superficial. Biology, applied to art, establishes a new, a biological aesthetic" (The Garden and Its Planting, 1913).

${ }^{3}$ The source of all references to Jens Jensen's correspondence is the Jens Jensen Collection, Sterling Morton Library, Lisle, Illinois.

${ }^{4}$ Nevertheless, it must be mentioned that Lange and other landscape architects who promoted ideas about natural garden design created formal gardens also and often used foreign plants. In particular, Lange recommended foreign plants that he believed matched the native plant associations physiognomically and that would heighten the artistic effect of native plant associations.

${ }^{5}$ For various attempts to connect garden architecture and national identity in the nineteenth and twentieth centuries, see G. Gröning \& U. Schneider, Garden Culture and National Identity, 2001.

Gert Gröning is professor of garden culture and open space development at the Institute for History and Theory of Design, University of the Arts Berlin. Joachim Wolschke-Bulmahn is a professor at the Institute for Planning and Garden Architecture, University of Hannover. "The Native Plant Enthusiasm" was originally published in Landscape Research (www.tandf.co.uk/journals/carfax/01426397.html) vol. 28 , no. 1 (2003), where a comprehensive set of notes and references are provided. 


\section{$2 \mathrm{BHL}$ Biodiversity Heritage Library}

Gröning, Gert and Wolschke-Bulmahn, Joachim. 2003. "The Native Plant Enthusiasm: Ecological Panacea or Xenophobia?" Arnoldia 62(4), 20-28.

View This Item Online: https://www.biodiversitylibrary.org/item/223251

Permalink: https://www.biodiversitylibrary.org/partpdf/251404

\section{Holding Institution}

Smithsonian Libraries

\section{Sponsored by}

Biodiversity Heritage Library

\section{Copyright \& Reuse}

Copyright Status: In Copyright. Digitized with the permission of the rights holder Rights Holder: Arnold Arboretum of Harvard University License: https://creativecommons.org/licenses/by-nc-sa/4.0/ Rights: https://www.biodiversitylibrary.org/permissions/

This document was created from content at the Biodiversity Heritage Library, the world's largest open access digital library for biodiversity literature and archives. Visit BHL at https://www.biodiversitylibrary.org. 